\title{
Environmental Virtue Ethics and the Sources of Normativity
}

\author{
Etyka cnót środowiskowych a źródła normatywności
}

\author{
Michał Piekarski \\ Institute of Philosophy, Cardinal Stefan Wyszynski University in Warsaw, Poland \\ ORCID: https://orcid.org/0000-0002-9482-526X•m.piekarski@uksw.edu.pl \\ Received: 09 Jun 2020; Revised: 10 Aug 2020; Accepted: 24 Aug 2020
}

\begin{abstract}
This article is an attempt to identify the sources of normativity in virtue ethics. The starting point for the analyzes presented here is the book by Dominika Dzwonkowska Environmental virtue ethics. In $\S 1$, I present the basic theses and assumptions of this approach to ethics. Then, with reference to the concept of the moral subject proposed by Dzwonkowska, I ask whether it constitutes the primary source of normativity ( $(2)$. I argue that environmental virtue ethics can be ascribed to arguments shared by supporters of the so-called constitutive arguments in metaethics ( $\S 3$ ). Their position is based on the recognition that moral norms, obligations, etc., derive from the constitutive features of the subject. I call such an approach internalist and contrast it with the non-internalist approach, the outline of which I propose in $\S 4$. In the Conclusion, I suggest that the pragmatic considerations and conservatism of researchers speak in favor of the internalist approach.
\end{abstract}

Keywords: environmental virtue ethics, normativity, moral subject, constitutive argument, internalism, externalism

Streszczenie: Niniejszy artykuł jest próbą wskazania źródeł normatywności w etyce cnót. Punktem wyjścia dla prezentowanych tutaj analiz jest książka Dominiki Dzwonkowskiej pt. Etyka cnót środowiskowych. W § 1 przedstawiam podstawowe tezy i założenia tego podejścia do etyki. Następnie odnoszę się do rozumienia podmiotu moralnego zaproponowanego przez Dzwonkowską i zadaję pytanie o to, czy stanowi on właściwe źródło normatywności (§ 2). Wykazuję, że propagatorom etyki cnót środowiskowych można przypisać argumentację podzielaną przez zwolenników tzw. argumentów konstytutywnych w metaetyce (§ 3). Ich stanowisko opiera się na uznaniu, że moralne normy, zobowiązania itd., wynikają z konstytutywnych cech podmiotu. Takie ujęcie określam mianem internalistycznego i przeciwstawiam je koncepcji eksternalistycznej, której zarys proponuję w $§ 4$. W Zakończeniu sugeruję, że za stanowiskiem internalistycznym przemawiają względy pragmatyczne i konserwatyzm badaczy.

Słowa kluczowe: etyka cnót środowiskowych, normatywność, podmiot moralny, argument konstytutywny, internalizm, eksternalizm 


\section{Introduction}

The emergence of environmental virtue ethics (hereinafter EVE) is directly related to the renaissance of interest in virtue ethics itself, stimulated by the publication of the article Modern Moral Philosophy by Elizabeth Anscombe (Anscombe 1958). Anscombe stated that the proper object of ethical reflection is the moral subject, and not questions about the goodness or rightness of a given action. The optics should therefore be changed, because both utilitarianism and deontology have proved ineffective in resolving moral problems. Anscombe suggests that ethicists should concentrate on the dispositions of the moral subject, which have been referred to as virtues since Aristotle. The ethical question, then, concerns what the subject should be, i.e. what dispositions he or she should have, and not whether a given act is good or bad. This is where the issue that I will deal with in this article arises, namely an attempt to answer the question formulated by Christine Korsgaard: what is the source of the concept of normativity (Korsgaard 1996, 10-11)? The answer to this question, as I will suggest, indicates the nature of the moral subject.

One of the problems that contemporary virtue ethics focuses on is the environmental crisis. Some authors (Hill 1983) argue that all activities related to the protection of the environment begin with the moral subject, because it is it's the "interior" that makes it capable of action. Others (Cafaro 2001) emphasize that virtue ethics cannot ignore the issue of virtues, because (1) focusing solely on rights and duties makes it impossible to indicate the correct way of life and moral direction of the subject's development; and (2) the reference to virtue can provide a strong (selfish) basis for environmental protection. And so, based on Cafaro's analyzes, it should be stated that contemporary EVE (1) complements utilitarian and deontological justifications for the protection of nature and the policies affecting the environment; (2) provides environmentally conscious solutions to achieve the goals of subjects; (3) by showing positive examples of how man and nature can coexist, contributes to changing the attitude of agents towards the environment; and (4) contributes to sustainable environmental improvement by focusing on specific character traits that are necessary for such improvement to be possible.

In her important book entitled Enviromental virtue ethics, Dominika Dzwonkowska proposes an original approach to EVE which is to be universalistic, positive and practical. Dzwonkowska justifies the necessity to adopt a perspective different from those present in the literature by citing certain shortcomings or weaknesses of earlier approaches. According to Dzwonkowska, it is crucial for EVE to take into account such features of virtues as their universality, positive character and practical dimension (Dzwonkowska 2019, Ch. 8) I will briefly discuss these features.

The universalistic nature of virtues implies that ethical principles and standards are universal. This means that ethical standards are to be binding on all moral subjects, because they are constant regardless of place and time. Dzwonkowska claims that such an approach to universalism is prone to various controversies and is not free from weaknesses. Instead, she proposes a stance narrowed down to the arethological and axiological issues, claiming that only virtues themselves, as moral dispositions of subjects, are universal, that is, "the same catalogues of virtues find application in different, even distant cultures" (Dzwonkowska 2019, 268). For Dzwonkowska, this means that virtues can be realized in various ways (formal difference), but their essence remains the same. The universal character of virtues is justified by the unchanging nature of human beings. The universality of environmental virtues, on the other hand, is justified by reference to the natural environment, which is a common good for all human moral subjects.

Dzwonkowska understands the positive nature of environmental virtues as the 
opposite of a tendency established in environmental protection which emphasizes negative elements, e.g. the heuristic of fear emphasized by Hans Jonas (Jonas 1984). It is fear, according to this philosopher, that determines that the moral subject begins to act towards nature protection. Positive elements do not have that impact. Dzwonkowska claims that this approach is wrong, because it is not justified in human nature, which is related to the fact that the human being avoids fear rather than lives it. For this reason, positive stimuli, e.g. emotions, are important. The point is that one should not measure the amount of evil that people can do, but the amount of good. Such an approach can lead to the development of positive habits, as Dzwonkowska points out after Mark Coeckelbergh (Coeckelberg 2015, 124). Coeckelbergh emphasizes, in line with David Hume's idea, that it is not reason that stimulates the moral subject to action, but emotions, which are the proper subject of human motivation. This means that environmental virtues depend on personal preferences that have been shaped since childhood.

The last important feature of environmental virtues, emphasized by Dzwonkowska, is their practical character. Generally speaking, it is associated with the possibility of referring to the realm of praxis. This means that moral skills should not only be important for theoretical discussions, but above all should have practical significance for the life of the subject: "a moral subject can claim to have a given skill only when he has applied it in a situation that requires it" (Dzwonkowska 2019, 284). Thus, virtues are to satisfied not only a specific criterion of knowledge, but also a specific pragmatic criterion. In this sense, virtues are moralized practical skills (Dzwonkowska 2019, 287).

Now, I can move on to a more detailed description of the moral subject. The aim of presented investigations is to show that EVE assumes that the subject is the source of normativity, which entails a number of theoretical difficulties. I will argue for the so-called non-internalistic approach. This approach assumes that the environment is the primary source of normativity. However, as I will show, this approach also implies a number of difficulties.

\section{Moral subject in environmental virtue ethics}

The concept of the moral subject is central to EVE. Of course, any ethics, regardless of its assumptions, will emphasize the essential or even primary role of the subject for the moral evaluation of actions, institutions and specific norms. Nevertheless, it is virtue ethics that makes the moral subject the central element in explaining the nature of morality and normativity, for "the sources of normativity are sought in the motivations and features of the moral subject" (Dzwonkowska 2019, 19). However, what distinguishes the concept of the moral subject in EVE from the understanding of the subject in other approaches is the emphasis on the role of virtues understood as practical skills focused on what is good. When talking about the moral subject, Dzwonkowska is not, however, fully consistent, as she uses several types of formulations to define the sources of normativity in relation to the moral subject. She writes about the "interior of the moral subject", "the moral subject itself", "moral skills", "human nature", "environmental virtues", and so on. This juxtaposition itself is not problematic for the analyses presented by the author, but it reveals a certain difficulty characteristic of virtue ethics as such. Namely, the status of the moral subject is not clear. What I mean is that virtue ethics does not justify the nature of the moral subject. For it is not clear whether the subject is empirical, transcendental or psychological. While this issue may seem secondary to the analysis of virtues themselves, it does reveal a problem area related to the nature of virtues as such. If, as Dzwonkowska claims, virtues are founded on human nature, are they innate, 
acquired in contact with the environment, or cultural? It seems that they are not culturally acquired because their property of universality contradicts this. On the other hand, the open question remains whether the fact that these virtues are universal is determined by a certain moral and cognitive architecture common to people, or rather by identical evolutionary and cultural conditions, or perhaps by a certain epistemic constitution (e.g. a priori forms of cognition). Dzwonkowska admonishes that the guarantor of the universality of virtues is human nature, which does not change over time, but does not specify whether we are talking about nature in a metaphysical or, for example, empirical sense, which could potentially lead to the thesis that the universal nature of our virtues is determined not by any necessary properties of our ontological structure, but by our common evolutionary history. If this were the case, it might turn out that beings with a different evolutionary constitution than ours would develop completely different virtues.

The above doubts are justified, because, depending on the answers to these questions, we will obtain certain consequences for the moral and epistemic sphere. In other words: it is impossible to say unequivocally how environmental virtues are constituted. It seems that the perspective adopted by Dominika Dzwonkowska, on the one hand leaves these questions unresolved, and on the other, shows that these are not "to be or not to be" questions for her version of EVE. It is possible to defend it by claiming that the questions I pose are important for theoretical problems facing ethics, but they are not important for the praxis sphere, which is to be the proper element of EVE (Dzwonkowska 2019, 284). This means that the question of the nature and constitution of the subject is not necessary for the effectiveness of its moral actions. The priority here is the question of the effectiveness of actions for environmental protection, and not their justification. This justification is important, but in view of the need to protect nature, it is a secondary, theoretical issue, and its resolution does not have to be of great importance for the problem of taking good environmental action. It is important for EVE to emphasize that the source of the motivation for such actions is the moral subject as such. Questions about whether it is its psychophysical structure, or the unchanging human nature, are questions that justify this source. In practice, this means that representatives of EVE do not have to answer them at all, because the basic ontic resolution has already been made. What is the resolution?

\section{Constitutive arguments in virtue ethics}

When analyzing the proposal of EVE in Dzwonkowska's approach, as well as general tendencies within virtue ethics as such, it should be stated that, for normativity and its special case, that is morality, the subject is a constitutive factor. This means that it is not so much the reason why we define certain objects, actions or persons as good (virtuous), right, wrong or unfair, but rather it is a necessary condition for the very possibility of this judgment. If my reconstruction of EVE is justified, then it should be stated that the proponents of this version of ethics are (at least in the most basic sense) in agreement with the supporters of the so-called constitutive arguments (see Korsgaard 1996; 2009; Rosati 2003; Velleman 2000).

The constitutive arguments are to explain the normative power of rational requirements in such a way that the recognition of moral imperatives, obligations, rules, etc., results from the constitutive characteristics of the subject of action, i.e. the moral subject. This means that it is not necessary to make assumptions about the existence of external properties or normative objects. According to this approach, the normativity of some requirements can be justified in a completely internalist manner, without referring to irreducible (to the subject) normative properties 
that would be outside the subject. ${ }^{1}$ Proponents of the use of constitutive arguments in ethics argue that, by recognizing the fundamental role that subjectivity plays in action, one can both indicate the source of its motivation and explain the rational grounds for the justification of the actions taken, which the acting subject attributes to himself as their perpetrator. Korsgaard argues that the requirements for action are dual in nature, being both descriptive and prescriptive. They are descriptive because they describe certain actions, and they are prescriptive because they sanction as flawed actions that do not comply with them. Recognising actions as compliant or non-compliant is associated here with the autonomy of the subject and the possibility of self-identification, i.e. the possibility of defining oneself as the responsible perpetrator of actions, which means that the condition for being an agent is the identification with the principle of choice on the basis of which one acts. Otherwise, the subject is not the subject but "a series of unrelated impulses" (Korsgaard 2009, 75-76).

The above argumentation is, I argue, analogous to the argumentative strategy used in EVE. Here, the requirement to care for nature, understood as effective and good actions for the protection of the environment, derives its normative power from the internal structure of the moral subject, which is constituted in such and such way. Dzwonkowska claims: "The key aspect of ecological arethology is the sphere of action and the issue of actions undertaken by a moral subject, motivated by a specific environmental virtue" (Dzwonkowska 2019, 291). This declaration confirms the proposed interpretation of EVE as constitutivism. This approach can also be described as ethical internalism, understood as an approach where sources of the motivation to act are searched for in the subject, i.e. inside it (keeping in mind my remarks regarding

1 However, there is no consensus among these authors as to what property (or set of properties) is constitutive of actions. However, the analysis of this problem exceeds the limits of this article. the ambiguity of this concept as used by Dzwonkowska). ${ }^{2}$ Such an approach, however, raises a certain difficulty, related to the basic assumption of the supporters of constitutive arguments according to which the subject is obliged to comply with certain normative requirements. ${ }^{3}$ It is possible to show some inconsistency in the case of a subject that does not comply with the normative requirements (Enoch 2006), i.e. does not act in accordance with the virtues it has. ${ }^{4}$ The proponents of constitutivism argue that when someone is involved in a "game" (e.g. environmental protection), he or she is bound by certain rules, so ignoring these rules is contrary to what the subject has already committed to. Thus, such a subject is in a sense irrational, as it both accepts and denies their normative power. This is problematic because the subject must accept a justification for accepting a given belief (e.g. that the environment should be protected) and be able to justify its rejection. ${ }^{5}$ According to this approach, the subject behaving in this way is inconsistent or irrational. However, we will not deny rationality to a person who for some reason breaks, for example, a specific order in the name of the so-called "higher" or "other" values. Enoch connects

2 Internalism understood in this way can, in a sense, be associated with the internalism of content, described by Wacław Janikowski: “Content internalism proclaims that practical reasons (including moral reasons) are true only as grounded in the set of desires possessed by a given subject (somebody's motivational set) (...) On the other hand, the externalism of the content claims that moral reasons that are not grounded in someone's set of desires can be true" (Janikowski 2007, 134).

3 This, in turn, is directly related to the question analyzed by me in $\$ 2$ about the way of justifying subjectivity in EVE.

4 Acting in accordance with the virtue possessed (assuming that the subject is aware of its possession) remains and open question in EVE

5 There are many cases when people who proclaim the need to protect the natural environment use air transport to promote their views, thus increasing their carbon footprint. 
the problematic nature of this approach with the belief that the reasons or beliefs that the subject considers obligatory cannot have their source outside that subject. This means that explaining compliance and noncompliance with certain requirements and their optimization has specific cognitive costs (Tversky and Kahnemann 1974) related to our evolutionary and computational constraints.

In the last parts of her book, Dzwonkowska, using Coeckelbergh's approach, weakens EVE's internalism. Namely, she writes that "internal virtues are not only an internal attribute (trait of character), nor an external action, but concern the way in which we operate in the world, as they refer to our relations with the environment" (Dzwonkowska 2019, 310). This declaration suggests that, notwithstanding the constitutive role of the subject, certain environmental conditions are also important. However, despite noticing and emphasizing the importance of the environment for the constitution of the moral actions of the subject, the burden of justifying them rests with the individual subject. The full justification of the hypothesis I propose is beyond the framework intended for these considerations, but I argue that the fundamental problem of whether EVE is internalist or externalist (in the sense formulated by me) is connected with determining the role of motivation played by the environment in the constitution of moral actions. I argue that the environment in EVE plays only a secondary role, because the subject is ultimately the source of motivation. I will now outline the theoretical possibility of an externalist EVE built around the concept of moral analogues of affordances.

\section{The possibility of non-internalistic environmental virtue ethics}

Eranda Jayawickreme and Anthony Chemero (Jayawickreme and Chemero 2008) argue that the affordance concept allows us to combine empirical research into moral human behavior with philosophical analyses of virtue. The concept of affordance was introduced by James J. Gibson (see Gibson 1979). He criticized traditional psychological and epistemological views that separate perception from action because, as he argued, in its most basic form, perception is a form of action. Separating perception from action leads to its separation from the environment in which it is realized. Organisms, however, do not perceive stimuli in a passive way, but they actively look for such stimulations that allow them to survive and cope with the environment and its threats. The animal is not a passive observer, but an active explorer, acquiring complex and structured information from its environment. Bearing in mind these assumptions, it should be stated that the actual object of perception is not the properties of objects, such as weight, length or height, but properties that are targeted at specific possibilities for action. In this regard, Gibson states, "that what we perceive when we look at objects are their affordances, not their qualities" (Gibson 1979, 134). "The affordances of the environment are what it offers the animal, what it provides or furnishes, either for good or ill. (...). I mean by it something that refers to both the environment and the animal in a way that no existing term does. It implies the complementarity of the animal and the environment" (Gibson 1979, 127).

Referring to Gibson's approach, Jayawickreme and Chemero define virtue as a moral analogue of affordances, and they define affordance itself as the relationship between the animal's abilities and such aspects of a given situation that enable the realization of a given skill (Jayawickreme, Chemero 2008, 121). For example, the affordance of "being-climbable" is the relationship between the ability to climb on objects and the height of a particular creature (Warren 1984). Its moral analogue is virtue understood as the ability to behave properly in morally important situations. How should this be understood?

Chemero emphasizes that affordances are normative (Chemero 2009). Affordances can be described by natural sciences in 
physical terms, but they also somehow oblige a creature to act appropriately in a given situation. This will be understood, claims Chemero, when it is recognized that affordances are closely related to the respective skills, skills that are inherently norm-governed. An ability or skill is defined by reference to what things are supposed to be as opposed to what they are now. An affordance is therefore the rule that determines the appropriate course of action. ${ }^{6}$ Returning to virtue as the moral analogue of affordances, it should be emphasized that it occurs in a situation in which an individual is to behave in the best possible way based on his ability to recognize specific affordances. In other words: a moral subject (returning to this concept) acts virtuously when this subject can behave relatively adequately in various situations. At this point, Jayawickreme and Chemero suggest that these are morally qualified situations. Here, I believe, their proposal encounters a serious problem.

The main problem with the theory of virtue based on the concept of affordances is distinguishing between situations qualified as moral and those without this qualification. It can of course be considered that all situations and actions are moral, i.e. good or bad, but such a solution raises further problems, for example the problem of the difference between the "morality" of an act such as climbing trees or climbing, and the morality of such acts as helping others or perjury. It seems that we should look for such a theory that would allow us to show the difference between events that are primarily and secondarily problematic from the moral point of view. Chemero and Jayawickreme theory does not provide any basis for such a distinction. Both authors move almost imperceptibly from examples of climbing trees to examples such as financial support for UNICEF. Why, in one case, is the application of a skill based on

6 For more on the relationship between affordances and normativity, see Wachowski 2018. affordances of a tree, while in the other, a skill is treated as a virtue, that is, the moral analogue of affordances? There is no direct answer to this question in the discussed theory. ${ }^{7}$

Although the approach proposed by Jayawickreme and Chemero is not without weaknesses, it does indicate the possibility of building a non-internalistic virtue ethics. In ethics understood in this way, the source of the subject's motivation for actions (including moral ones) is affordances, i.e. relational properties whose poles are specific properties of the environment and the subject's abilities or skills. In the account based on the source of motivation external to the subject, one can defend a certain form of ethical realism which sees the sources of normativity in specific objects or relational structures, and not in the internal constitution of the subject.

\section{Conclusion}

The presented analysis is far from complete. My goal was to emphasize an unspoken thread in the vision of EVE proposed by Dominika Dzwonkowska and to indicate the possibility of building non-internalist virtue ethics which would look for sources of normativity and motivation of the subject beyond the subject as such. However, I did not intend to evaluate or indicate which of these visions is better or more adequate for the problems of environmental protection because, in the current situation, Dzwonkowska's proposal undoubtedly fulfils this goal better, even though it is a human, resp. the subject, who becomes the measure of what is normative, resp. moral. This may be risky as the subject is

7 When Gibson and his successors speak of affordances, they apply them not only to humans but also to animals. It is enough to take a quick look at the terms Gibson (1979) and Chemero (2009) use. Affordances are closely related to the skills of the animals. This belief is not uncontroversial and is related, inter alia, to the anti-representational thesis. However, the analysis of these issues is beyond the scope of this article. 
placed in a dominant position in relation to the environment. Thus it is necessary to constantly transcend this perspective and justify the environment's validity. The non-internalist virtue ethics approach changes the internalistic perspective. Namely, as Gibson has shown, the approach assuming the division into subject and object is replaced by a relational one in which affordances are the guarantor of the relationship between the subject and the object, resp. the environment. According to Gibson, the latter is to be neither subjective nor objective (Gibson 1979 , 129). Unfortunately, non-internalist virtue ethics encounters a number of difficulties, some of which I have mentioned above. It may turn out in the end that for pragmatic and rhetorical reasons and also due to the conservatism of researchers, the non-trivial understanding of virtues as environmental skills must be based on the concept of the subject, not the environment. ${ }^{8}$

\section{Bibliography}

Anscombe, Elizabeth. 1958. „Modern Moral Philosophy." Philosophy 33: 1-19.

Cafaro, Philip. 2001. „Thoreau, Leopold, and Carson: Towards an Environmental Virtue Ethics.” Environmental Ethics 1: 3-17.

Chemero, Anthony. 2009. Radical Embodied Cognitive Science. Cambridge, Massachusetts: Massachusetts Institute of Technology Press.

Coeckelbergh, Mark. 2015. Environmental Skill. Motivation, Knowledge, and the Possibility of a Non-Romantic Environmental Ethics. New York: Routlege.

Dzwonkowska, Dominika. 2019. Etyka cnót środowiskowych. Warszawa: Wydawnictwo Naukowe Uniwersytetu Kardynała Stefana Wyszyńskiego.

Enoch. David. 2006. „Agency, Schmagency: Why Normativity Won't Come from What Is Constitutive of Action." Philosophical Review 115: 169-198.

8 Stanford (2019) shows that the conservatism of researchers can have an influence on the difficulties associated with changing theoretical positions.
Gibson, James J. 1979. The Ecological Approach to Visual Perception. New York: Psychology Press. Hill, Te. 1983. „Ideals of Human Excellence and Preserving Natural Environment." Environmental Ethics 3: 211-224.

Janikowski, Wacław. 2007. “Określenie pojęć internalizmu i eksternalizmu etycznego." Etyka 40: $130-143$.

Jayawickreme, Eranda, and Anthony Chemero. 2008. "Ecological Moral Realism." Review of General Psychology 12: 118-126.

Jonas, Hans. 1984. The Imperative of Responsibility: In Search of an Ethics for the Technological Age. Chicago: University of Chicago Press.

Korsgaard, Christine. 1996. The Sources of Normativity. New York: Cambridge University Press.

Korsgaard, Christine. 2009. Self-Constitution: Agency, Identity, and Integrity. Oxford: Oxford University Press.

Rosati, Connie S. 2003. "Agency and the Open Question Argument.” Ethics 113: 490-527.

Stanford, Kyle P. 2019. "Unconceived Alternatives and Conservatism in Science: The Impact of Professionalization, Peer-review, and Big Science." Synthese 196(10): 3915-3932. https://doi. org/10.1007/s11229-015-0856-4.

Tversky, Amos, and Daniel Kahneman. 1974. "Judgment under Uncertainty: Heuristics and Biases." Science 4157(185): 1124-1131. https://doi. org/10.1126/science.185.4157.1124.

Velleman, J. David. 2000. The Possibility of Practical Reason. Oxford: Oxford University Press.

Wachowski, Witold M. 2018. „Normatywność usytuowana. Ujęcie ekologiczne." Studia Philosophiae Christianae 1(54): 143-165. https:// doi.org/10.21697/spch.2018.54.1.16.

Warren, William H. 1984. "Perceiving affordances: Visual guidance of stair climbing." Journal of Experimental Psychology: Human Perception and Performance 10(5): 683-703. 